\title{
CONTRIBUIÇÃO DA ABEn PARA DIVULGAÇÃO DO CONHECIMENTO PRODUZIDO PELA ENFERMAGEM BRASILEIRA
}

Joel Rolim Mancia ${ }^{1}$

A Comissão de Publicações (CP-ABEn) da ABEn criada em dezembro de 2001 por iniciativa do Conselho Editorial da REBEn justificou-se pelo pleno reconhecimento, em diversos fóruns da categoria, da necessidade da ABEn consolidar-se como editora, porque já havia adquirido as condições para desenvolver e manter o alcance, o porte e a regularidade exigidos pelas atuais demandas profissionais. Assim as publicações da ABEn, por meio de qualificação editorial e normalização, com vistas ao reconhecimento das mesmas pela comunidade acadêmica e profissional, bem como contribuir com a consolidação do compromisso da entidade na construção e desenvolvimento do projeto político da enfermagem brasileira, passam por modificações como o periódico Informações sobre Pesquisas e Pesquisadores em Enfermagem, que será disponibilizado somente na internet, constituindo-se na segunda publicação eletrônica da ABEn.

A CP-ABEn nasceu para propor a qualificação dos produtos intelectuais da Associação. No entanto já vínhamos desenvolvendo em nossos eventos atividades mais amplas que se voltavam também para o meio editorial da enfermagem. Assim a ABEn propõe o Encontro Nacional de Editores de Periódicos de Enfermagem, que tem provocado uma discussão mais qualificada com os editores. $\mathrm{E}$ com este, culminou, em 2002, a criação da Comissão Editorial CAPES/ABEn. Em momento anterior, nesse encontro foi apresentado o levantamento: Situação dos Periódicos de Enfermagem no Brasil, documento que possibilitou um primeiro diagnóstico dessas publicações e que foi utilizado pela CAPES para avaliação dos periódicos daquele ano.

O projeto de atuação da CP-ABEn articulado com a CAPES e Programas de Pós-Graduação, mais do que uma intenção se constitui num gesto para fortalecer a expressão social da profissão e a visibilidade de sua produção científica, comprometendo a academia, os serviços e a organização associativa.

Como editora a ABEn tem publicado regularmente: a Revista Brasileira de Enfermagem, os livros com temas dos Congressos, Seminários e Encontros, os Anais; a série Informações de Pesquisa e Pesquisadores em Enfermagem; livros-resumo dos eventos da Associação com os resumos de temas livre apresentados; a série didática- Enfermagem no SUS coletânea que relatou todo o projeto CIPESC, num total de 7 livros; a série histórica, com obras que contam a história da própria Associação.

Em nossos editoriais temos apontado para todas as questões que se relacionam com as revistas, inclusive o financiamento. De forma que a maioria das publicações são patrocinadas por instituições públicas, ao que parece, pelo resultado do levantamento, anteriormente mencionado, as assinaturas pagas não têm um papel significativo na sobrevivência do periódico, tendo a tiragem mostrado crescimento em poucos periódicos.

Em boa hora chega à ABEn o documento: Estratégias de Ação da Pós-Graduação da Enfermagem Brasileira - proposições, trazendo proposta concreta para contribuir nas questões de publicação em enfermagem. Trata de ações que visam implementar as publicações de enfermagem no Brasil. A proposta, no conjunto, se articula com a Associação Brasileira de Enfermagem o que não poderia ser diferente já que a ABEn é assim o "Ministério da Enfermagem".

Esta parceria estimulará a permanência da Comissão Editorial CAPES/ABEn, o que acreditamos ser fundamental para o desenvolvimento dos periódicos de enfermagem no Brasil.

A Comissão CAPES/ABEn para avaliação de periódicos estará reunida no $12^{\circ} \mathrm{SENPE}$, tendo como pauta a elaboração de um instrumento específico da enfermagem para a avaliação dos nossos peródicos.

\section{REBEn TEMÁTICA}

Para registrar os desafios na implementação de projetos pedagógicos face às diretrizes curriculares nacionais para os cursos de enfermagem, estaremos publicando um número com a temática Educação em Enfermagem.

Convidamos todos a participarem enviando seus originais para reben.educ@terra.com.br até 31 de agosto de 2003. Aceitaremos para avaliação textos com até 15 páginas, empregando citações e referências, segundo Vancouver. 